\title{
SIMULTANEOUS RP-HPLC METHOD DEVELOPMENT AND IT'S VALIDATION FOR ESTIMATION OF SOFOSBUVIR AND VELPATASVIR IN THEIR COMBINED DOSAGE FORM
}

\author{
J. Mamatha ${ }^{1, *}$ and N. Devanna ${ }^{2}$ \\ ${ }^{1}$ Faculty of Chemistry G. Pullaiah College of Engineering and Technology. \\ A.P. State. \\ ${ }^{2}$ Faculty of Chemistry, JNTU College of Engineering, Anantapuramu, A.P. State \\ *E-mail: mamatha@gpcet.ac.in
}

\begin{abstract}
A new simple and precise simultaneous RP-HPLC method was developed and validated for the identification and analysis of fixed dose combination of Sofosbuvir and velpatasvir in their combined tablet dosage form. The excipients in the tablet form showed no intervention with the analyte chromatograms. The retention time of sofosbuvir was 3.049 minutes and velpatasvir was 4.316 minutes respectively. The developed method was validated for linearity, specificity, accuracy, robustness and ruggedness according to $1 \mathrm{CH}$ instructions. The limit of detection were $0.475 \mathrm{ppm}$ and $0.65 \mathrm{ppm}$ and the limit of quantification were $1.44 \mathrm{ppm}$ and $1.98 \mathrm{ppm}$ for Sofosbuvir and Velpatasvir respectively.

The drug content assay in the tablet was closer to $100 \%$. All the validated parameters met the acceptance criteria. The developed method can be used in quality control analysis.

Keywords: Sofosbuvir, Velpatasvir, RP-HPLC, Validation, ICH Guidelines.
\end{abstract}

(c) RASĀYAN. All rights reserved

\section{INTRODUCTION}

Hepatitis $\mathrm{C}$ virus (HCV) infection is a major health attack and is the most common cause of liver transplantation. $\mathrm{HCV}^{1}$ has specific Ribonucleic acid (RNA) sequence variance and based on this $\mathrm{HCV}$ is classified in to not less than 6 genotypes. Along with the rising new treatments, including interferon - free regimens, still a better treatment is looked out for $\mathrm{HCV}$ infection of genotype 2 and 3 and for severe liver disease. Sofosbuvir ${ }^{2}$ (SOF), Fig.-1 has a molecular mass of 529 gram per mol, molecular formula of $\mathrm{C}_{22} \mathrm{H}_{29} \mathrm{FN}_{3} \mathrm{O}_{9} \mathrm{P}$ and has IUPAC name, as:

(S)-Isopropyl-2-((S)-(((2R，3R，4R，5R)-5-(2，4-dioxo-3，4-dihydropyrimidin-1 (2H)-yl)-4-fluoro-3hydroxyl-4-methyltetrahydrofuran-2-yl) methoxy)-(phenoxy) phosphorylamino) propanoate.

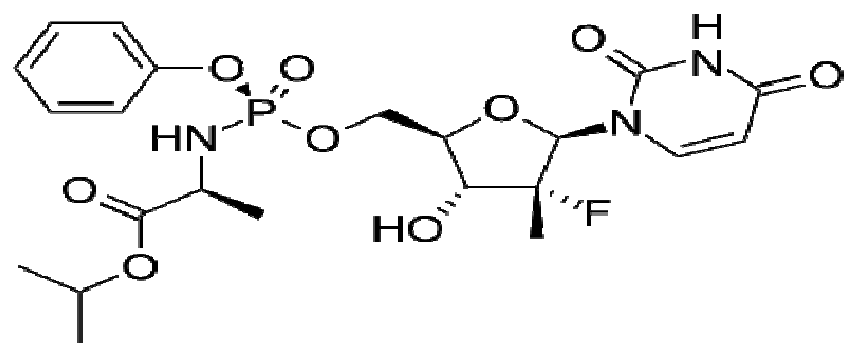

Fig.-1: Sofosbuvir

SOF is a nucleotide precursor drug that is converted into active uridine triphosphate form with in the liver cell. SOF inhibits the activity of HCV nonstructural protein (NS) 5B polymerase nucleotide and thus prevent HCV RNA replication through chain termination.

Rasayan J. Chem., 11(1), 392-400(2018)

http://dx.doi.org/10.7324/RJC.2018.1111931 
Velpatasvir ${ }^{3}$ (VEL), Fig.-2, has molecular formula $\mathrm{C}_{49} \mathrm{H}_{54} \mathrm{~N}_{8} \mathrm{O}_{8}$ molecular mass 883.0 gram per mole and has IUPAC name Methyl \{(1R)-2-[(2S,4S)-2-(5-\{2-[(2S, 5S)-1-\{(2S)-2-[(Methoxycarbonyl) amino]-3methylbutanoyl $\}-5$-methylpyrrolidin-2-yl]-1, 11-dihydro [2] benzopyrano $\left[4^{1}, 3^{1}: 6\right.$, 7] naphtho [1, 2-d] imidazole-9-yl -1H-imidazol-2-yl)-4-(methoxymethyl) carbamate.

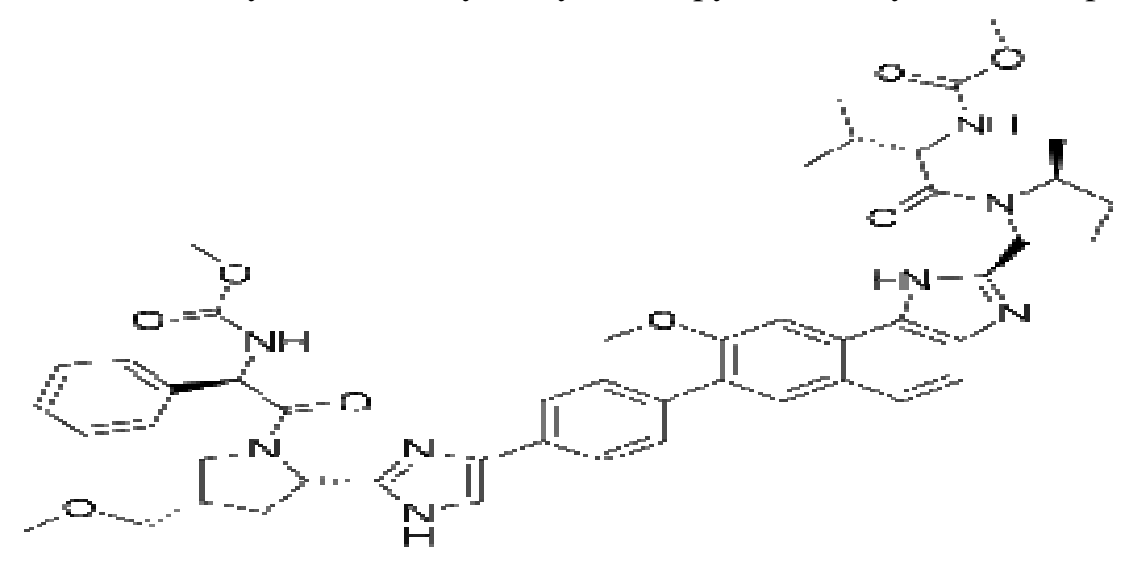

Fig.-2: Velpatasvir

VEL works by preventing the HCV non - structural protein 5A (NS5A) from playing its role both in viral replication and arrangement of HCV virions. SOF and VEL together show significant antiviral properties due to added antiviral interaction of both the drugs and also lack of cross resistance between them.

SOF/VEL is a quick release fixed dose combination tablet containing 400mg SOF and 100mg VEL effective in the treatment of HCV infection in adults.

Previous works involving analytical method development (MD) and its validation using RP-HPLC related to SOF included SOF determination in pure form ${ }^{4}$, Estimation and validation of SOF in bulk and tablet form $^{5}$, simultaneous determination of SOF along with Ledipasvir in tablet form and also its application to in vitro Dissolution studies ${ }^{6}$, simultaneous study of SOF along with simeprevir ${ }^{7}$ ultraviolet visible spectroscope method for estimation of Daclatasvir and $\mathrm{SOF}^{8,}$ Determination of SOF from Human plasma ${ }^{9}$. NO RP-HPLC work is published related to VEL.

The present study concentrates on simultaneous RP-HPLC MD and its validation in a novel fixed dose combination tablet of SOF and VEL following the $\mathrm{ICH}^{10}$ directions.

\section{Chemicals}

\section{EXPERIMENTAL}

The Pure active pharmaceutical ingredient (AP1) sample of SOF and VEL were given on request from Jigs chemical. Ahmedabad Sofosvel, a combination tablet of SOF 400 milligram (mg) and VEL 100mg was purchased from the distributor.

Methanol (Met), dipotassium hydrogen phosphate (DPHP), Potassium dihydrogen phosphate (PDHP), Orthophosphoric acid (OPA) all of HPLC grade were purchased from Merck limited.

HPLC grade water was used to prepare the buffer. MP was used as the diluent. All the prepared solutions were microfiltered and agitated in an ultrasonic probe before use in HPLC instrument.

\section{Preparation of Standard Solutions SOF Stock solution (SS)}

$100 \mathrm{mg}$ of SOF pure AP1 sample was dissolved and diluted with the M.P in a 100ml volumetric flask up to the mark to get a solution of $1000 \mathrm{ppm}$.

\section{VEL SS}

$100 \mathrm{mg}$ of VEL pure API sample dissolved and diluted with the M.P in a 100ml volumetric flask up to the mark to get a solution of $1000 \mathrm{ppm}$. 


\section{RASĀYAN J. Chem.}

Vol. 11 | No. 1 |392 - 400 | January - March | 2018

\section{Working standard (WS) Solution}

WS solution of SOF and VEL was prepared by adding 4ml of SOF SS and $1 \mathrm{ml}$ of VEL SS together into a single $100 \mathrm{ml}$ volumetric flask and diluted up to the mark to get a concentration of $40 \mathrm{ppm}$ SOF and 10 ppm VEL.

\section{Test Sample (TS) Solution}

Ten Sofosvel tablets having a dosage of SOF 400mg and VEL 100mg were weighed and average weight of single tablet noted. These tablets were powdered and weight of powder equal to one tablet weight was introduced into a single $100 \mathrm{ml}$ flask, dissolved and diluted up to the mark with MP.

The above solution was further diluted in the right proportion to get a concentration of $40 \mathrm{ppm} \mathrm{SOF}$ and 10 ppm VEL test sample solution.

\section{Linearity range solutions}

Linearity series solutions ranging from $20 \mathrm{ppm}$ to $80 \mathrm{ppm}$ with respect to both the drugs were prepared in combination with SOF 2 microgram per milliliter $(\mu \mathrm{g} / \mathrm{ml})$ to $8 \mu \mathrm{g} / \mathrm{ml}$ and VEL $(0.5 \mu \mathrm{g} / \mathrm{ml}$ to $2 \mu \mathrm{g} / \mathrm{ml})$ respectively.

\section{Preparation of Phosphate Buffer}

6.67 grams of PDHP and 8.55 grams of DPHP were dissolved and diluted with HPLC grade water in a $1000 \mathrm{ml}$ beaker. The $\mathrm{pH}$ of the solution was adjusted to 3.2 with OPA.

\section{M.P Preparation}

It consisted of degassed Methanol and phosphate buffer in 60: $40 \mathrm{~V} / \mathrm{V}$ ratio.

Table-1: Instrumentation

\begin{tabular}{c|c}
\hline HPLC Instrument & Waters 2695 Alliance HPLC system \\
\hline Detector & 996 Photodiode Array detector \\
\hline Data acquisition & Empower software \\
\hline Electronic balance & Sartorius \\
\hline Ultrasonic probe & Fast clean \\
\hline
\end{tabular}

\section{Simultaneous RP HPLC MD}

MP was eluted isocratically at ambient temperature on a C-18 column maintaining $1 \mathrm{ml} / \mathrm{min}$ flow rate for $20 \mu 1$ sample volume and total runtime of 8 minutes.

The data analysis report showed Retention time (RT) of $3.048 \mathrm{~min}$ and $4.316 \mathrm{~min}$ for SOF and VEL in the API standard and in the TS the RT for SOF and VEL were 3.049 min and 4.316 min respectively.

Table-2: Optimized Chromatographic Conditions

\begin{tabular}{l|l}
\hline Column & Inertsil C-18 $(250 \times 4.6 \mathrm{~mm}, 5$ micron $)$ \\
\hline Mobile Phase (MP) & Methanol : Buffer $(60: 40)$ V/V volume ratio \\
\hline Flow rate (FR) & 1 milliliter per minute $(\mathrm{ml} / \mathrm{min})$ \\
\hline Run time & 8 min \\
\hline Column temperatures (temp) & Ambient \\
\hline Sample volume & 20 microliters $(\mu \mathrm{l})$ \\
\hline Maximum absorbance wavelength & 254 nanometers $(\mathrm{nm})$ \\
\hline Micro Filter pore size & 0.45 micrometers $(\mu \mathrm{m})$ \\
\hline Buffer pH & 3.2 \\
\hline
\end{tabular}

\section{Method Validation}

The developed method was validated as per the ICH instructions for system suitability (ST), specificity, linearity, Accuracy (Recovery), precision, Ruggedness, Robustness, Limit of detection (LOD) and limit of Quantification (LOQ). 


\section{RASĀYAN J. Chem.}

Vol. 11 | No. 1 |392 - 400 | January - March | 2018

\section{S.T (SOF)}

\section{RESULTS AND DISCUSSION}

WS solution of SOF and VEL were injected five times into the HPLC system and the ST parameters were evaluated from the standard chromatograms. The percent relative standard deviation (\% RSD) for RT and PA were calculated. All the ST validation data for SOF (Table-3) and VEL (Table-4) met the criteria.

Table-3: S.T (SOF)

\begin{tabular}{c|c|c|c|c}
\hline Injection & RT $(\min )$ & PA & Theoretical plate count & Tailing factor \\
\hline 1 & 3.048 & 9438247 & 11023.845712 & 1.14721 \\
\hline 2 & 3.049 & 9436021 & 11010.547812 & 1.13384 \\
\hline 3 & 3.047 & 9431581 & 11036.874214 & 1.18742 \\
\hline 4 & 3.048 & 9432036 & 11027.254178 & 1.16547 \\
\hline 5 & 3.047 & 9433819 & 11084.658952 & 1.17485 \\
\hline Mean & 3.0478 & 9434755 & 11036.825171 & 1.1852313 \\
\hline SD & 0.000837 & 3358.178 & - & - \\
\hline \% RSD & 0.027451 & 0.270438 & & \\
\hline
\end{tabular}

\section{Specificity}

The Blank chromatogram (Fig.-3) depicted no peak at the RT of the analytes. The chromatogram of the AP1 (Fig.-4) and TS (Fig.-5) depicted almost identical RT for SOF and VEL. The excipients present in the tablet dosage form showed no interfering peaks. The developed simultaneous RP - HPLC method was specific.

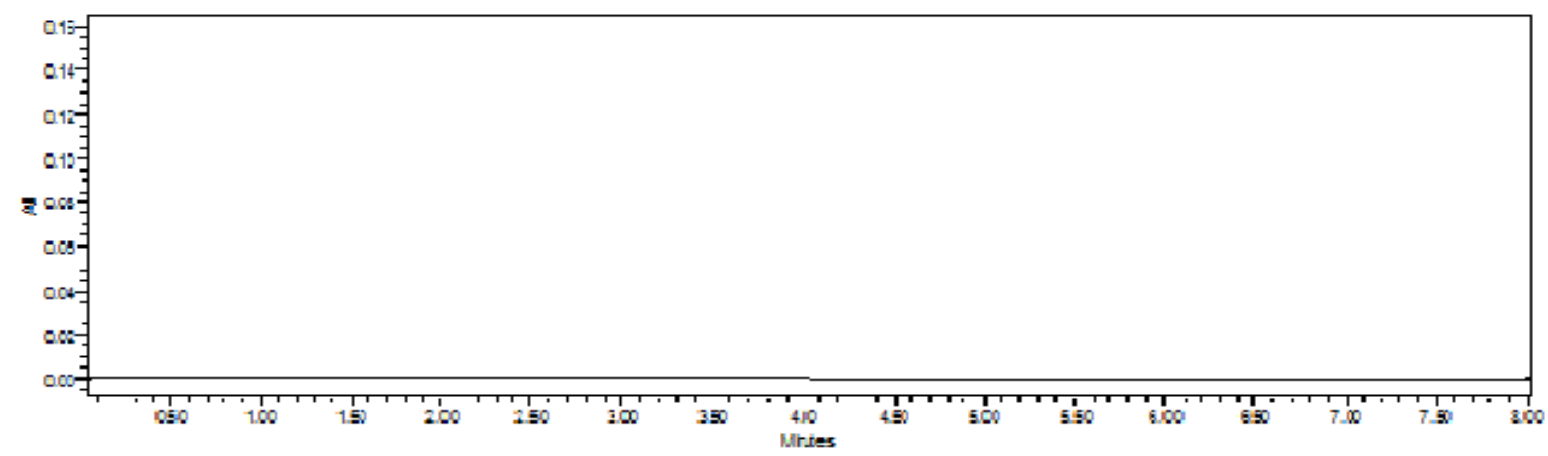

Fig.-3: Blank Chromatogram

Table-4: S.T (VEL)

\begin{tabular}{c|c|c|c|c}
\hline Injection & RT $(\mathrm{min})$ & PA & Theoretical plate count & Tailing factor \\
\hline 1 & 4.316 & 323209 & 8325.874512 & 1.284572 \\
\hline 2 & 4.316 & 323181 & 8384.547862 & 1.254872 \\
\hline 3 & 4.312 & 323028 & 8314.875424 & 1.278451 \\
\hline 4 & 4.317 & 323915 & 8372.784518 & 1.287451 \\
\hline 5 & 4.313 & 324059 & 8392.084512 & 1.298745 \\
\hline SD & 0.002168 & 1588.8 & & - \\
\hline
\end{tabular}

\section{Linearity}

Linearity was studied in the range of 20ppm to $80 \mathrm{ppm}$ with respect to both SOF and VEL (Table-5). For each linearity level solution 3 chromatograms were recorded. A good linear relationship was observed between the average PA and the solution concentration in ppm within the range $(2 \mu \mathrm{g} / \mathrm{ml}$ to $8 \mu \mathrm{g} / \mathrm{ml})$ for SOF (Fig.-6) and $(0.5 \mu \mathrm{g} / \mathrm{ml}$ to $2 \mu \mathrm{g} / \mathrm{ml}$ ) for VEL (Fig. -7$)$. Strong linear relationship was proved by high value of correlation coefficient (r) which was 0.999 for SOF and VEL. 
RASĀYAN J. Chem.

Vol. 11 | No. 1 |392 - 400 | January - March | 2018

Table-5: Linearity

\begin{tabular}{c|c|c}
\hline Concentration $(\mathrm{ppm})$ & Average PA (SOF) & Average PA (VEL) \\
\hline 0 & 0 & 0 \\
\hline 20 & 4719376 & 161774 \\
\hline 30 & 7079064 & 242661 \\
\hline 40 & 9438751 & 323547 \\
\hline 50 & 11798439 & 404434 \\
\hline 60 & 14158127 & 485321 \\
\hline 70 & 16517815 & 566208 \\
\hline 80 & 18477503 & 637095 \\
\hline Slope & 23306 & 8016 \\
\hline Y - intercept & 77193 & 1929 \\
\hline & 0.999 & 0.999 \\
\hline
\end{tabular}
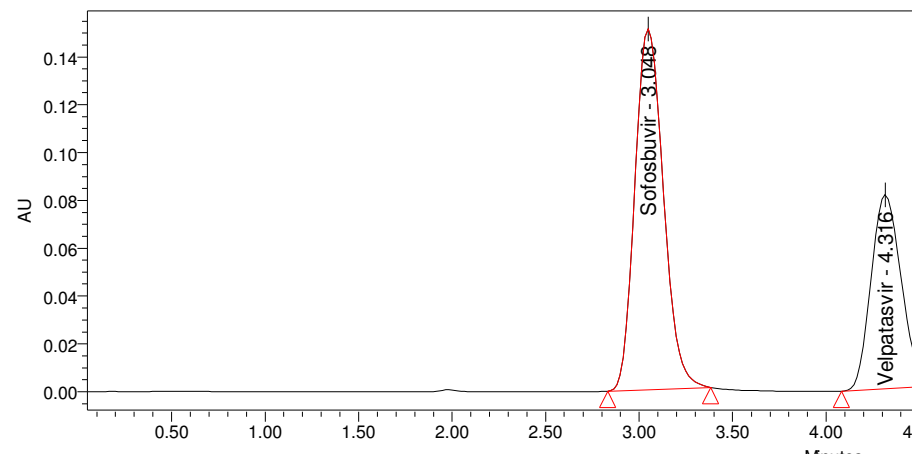

Minutes

\begin{tabular}{|l|l|r|r|r|r|r|r|r|r|}
\hline & Name & $\begin{array}{c}\text { Retention } \\
\text { Time }\end{array}$ & \multicolumn{1}{|c|}{ Area } & \% Area & Height & $\begin{array}{c}\text { USP } \\
\text { Resolution }\end{array}$ & $\begin{array}{c}\text { USP } \\
\text { Tailing }\end{array}$ & $\begin{array}{c}\text { Asymmetry } \\
\text { Factor }\end{array}$ & $\begin{array}{c}\text { USP Plate } \\
\text { Count }\end{array}$ \\
\hline 1 & Sofosbuvir & 3.048 & 9438247 & 63.71 & 150828 & & 1.14721 & 1.087451 & 11023.845712 \\
\hline 2 & Velpatasvir & 4.316 & 323209 & 36.29 & 81160 & 4.342819 & 1.1284572 & 1.087541 & 8325.874512 \\
\hline
\end{tabular}

Fig.-4: Standard Chromatogram of SOF/VEL

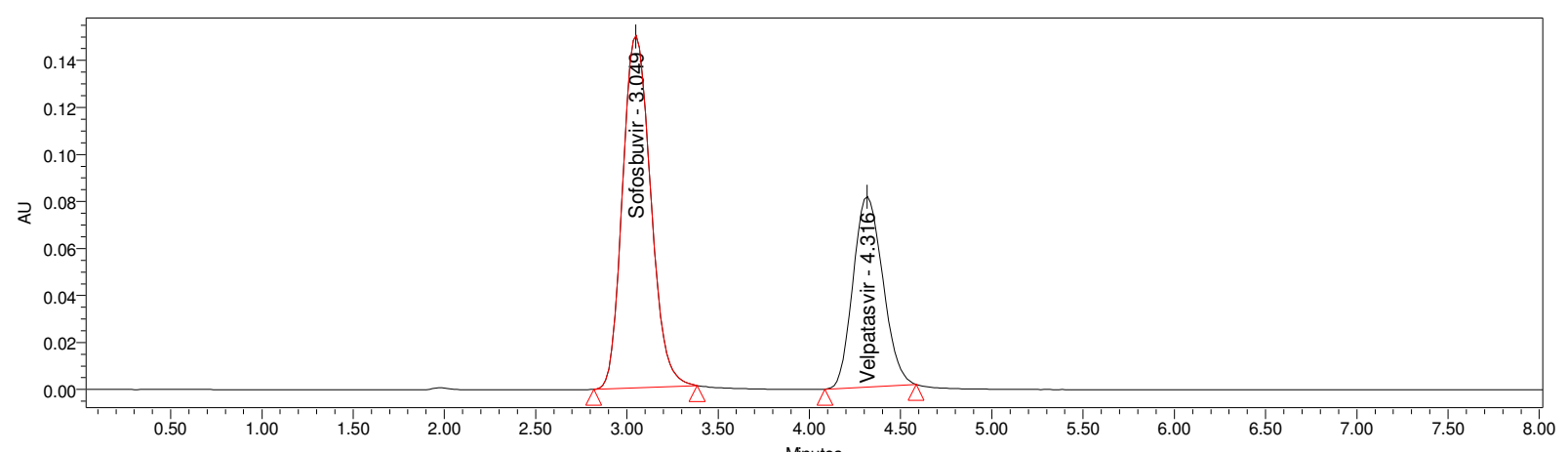

\begin{tabular}{|l|l|r|r|r|r|r|r|r|r|}
\hline & Name & \multicolumn{1}{|c|}{$\begin{array}{c}\text { Retention } \\
\text { Time }\end{array}$} & \multicolumn{1}{|c|}{ Area } & \% Area & Height & $\begin{array}{c}\text { USP } \\
\text { Resolution }\end{array}$ & $\begin{array}{c}\text { USP } \\
\text { Tailing }\end{array}$ & $\begin{array}{c}\text { Asymmetry } \\
\text { Factor }\end{array}$ & $\begin{array}{c}\text { USP Plate } \\
\text { Count }\end{array}$ \\
\hline 1 & Sofosbuvir & 3.049 & 9436021 & 63.71 & 149923 & & 1.13384 & 1.089624 & 11010.547812 \\
\hline 2 & Velpatasvir & 4.316 & 323181 & 36.29 & 80992 & 4.297313 & 1.254872 & 1.087632 & 8384.547862 \\
\hline
\end{tabular}

Fig.-5: TS chromatogram SOF / VEL

\section{Accuracy}

Drug assay was conducted thrice as per test method for each spike level solution which consisted of SOF and VEL concentration equal to 50\%, 100\% and $150 \%$ of the label amount. The average \% recovery of 
Vol. 11 | No. 1 |392 - 400 | January - March | 2018

SOF and VEL were calculated from each chromatogram. The \% recovery from all the three level solutions for SOF and VEL were closer to 100 and met the acceptance limits (Table-6, Fig.-8, and Fig.-9).

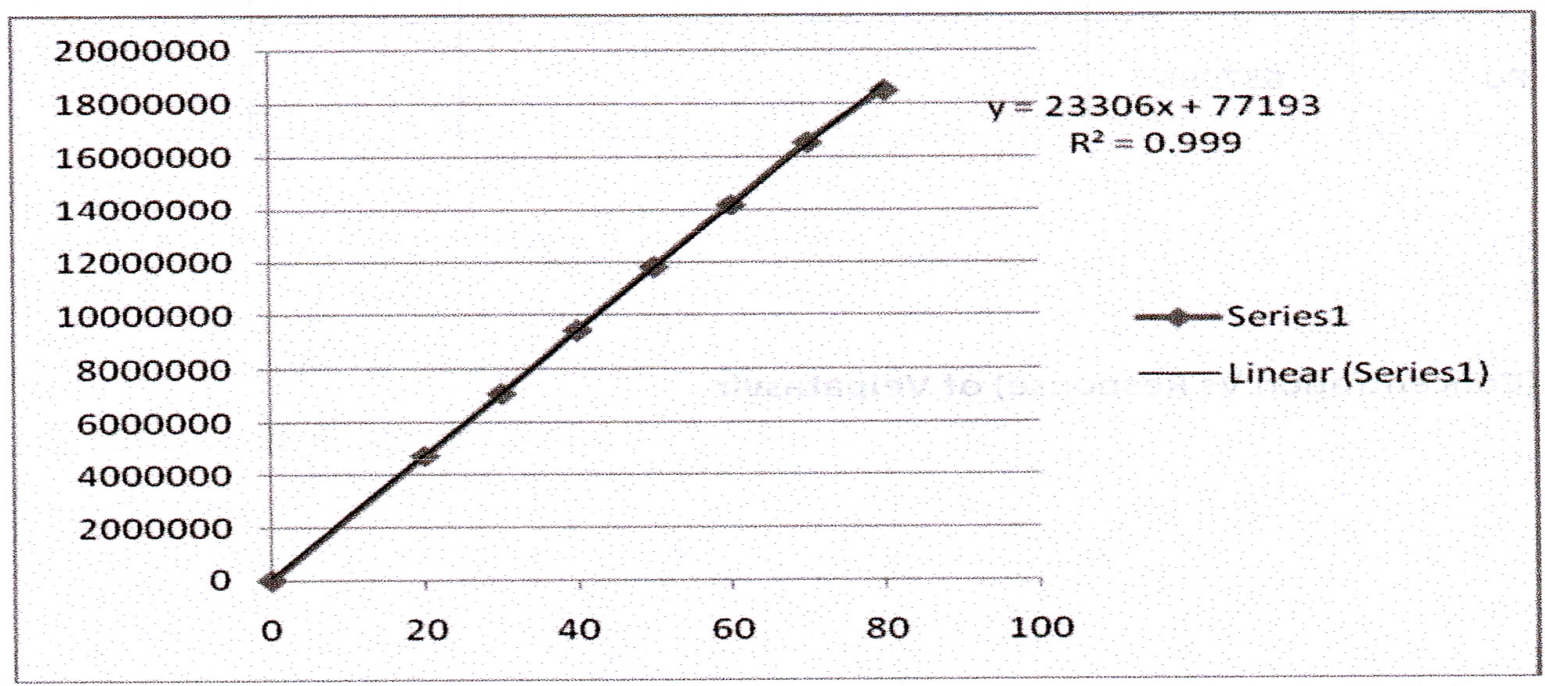

Fig.-6: Linearity Graph (SOF)

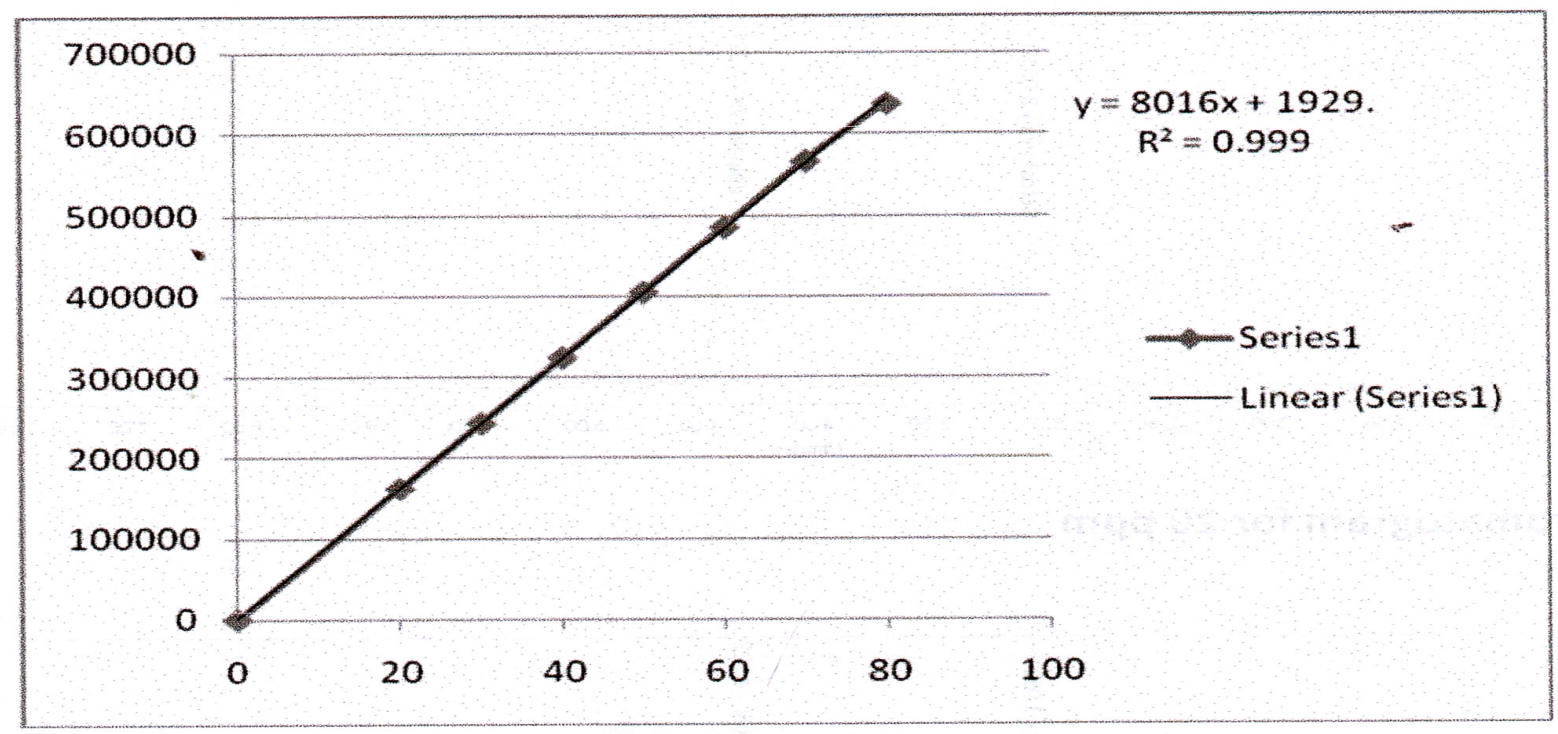

Fig.-7: Linearity Graph (VEL)

Table-6: Accuracy

\begin{tabular}{c|l|l|l|l|l|l|l}
\hline \multirow{2}{*}{$\begin{array}{c}\text { Spike level } \\
\text { concentration }\end{array}$} & \multicolumn{3}{c|}{ SOF } & \multicolumn{2}{c}{ VEL } \\
\cline { 3 - 8 } & $\begin{array}{c}\text { Amount } \\
\text { added } \\
(\mathrm{ppm})\end{array}$ & $\begin{array}{c}\text { Amount } \\
\text { Recovered } \\
(\mathrm{ppm})\end{array}$ & $\begin{array}{c}\% \\
\text { Recovery }\end{array}$ & $\begin{array}{c}\text { Amount } \\
\text { added } \\
(\mathrm{ppm})\end{array}$ & $\begin{array}{c}\text { Amount } \\
\text { Recovered } \\
(\mathrm{PPM})\end{array}$ & $\begin{array}{c}\% \\
\text { Recovery }\end{array}$ \\
\hline & Injections & 20 & 20.01 & 100.05 & 20 & 20.45 & 102.25 \\
\hline $50 \%$ & 1 & 20 & 19.91 & 99.5 & 20 & 19.84 & 99.2 \\
\hline & 2 & 20 & 20.08 & 100.4 & 20 & 20.07 & 100.35 \\
\hline $100 \%$ & 3 & 40 & 40.03 & 100.07 & 40 & 39.45 & 98.62 \\
\hline & 2 & 40 & 39.98 & 99.95 & 40 & 40.07 & 100.17 \\
\hline $150 \%$ & 3 & 40 & 39.91 & 99.77 & 40 & 39.93 & 99.82 \\
\hline & 1 & 60 & 60.02 & 100.03 & 60 & 60.02 & 100.03 \\
\hline
\end{tabular}


RASĀYAN $J$. Chem.

Vol. 11 | No. 1 |392 - 400 | January - March | 2018

\begin{tabular}{l|l|l|l|l|l|l|l}
\hline & 2 & 60 & 60.07 & 100.11 & 60 & 59.98 & 99.96 \\
\hline & 3 & 60 & 60.04 & 100.06 & 60 & 60.07 & 100.11 \\
\hline & & & Mean & 99.993 & & & 100.05 \\
\hline & & & $\%$ RSD & 0.68 & & & 0.327 \\
\hline
\end{tabular}

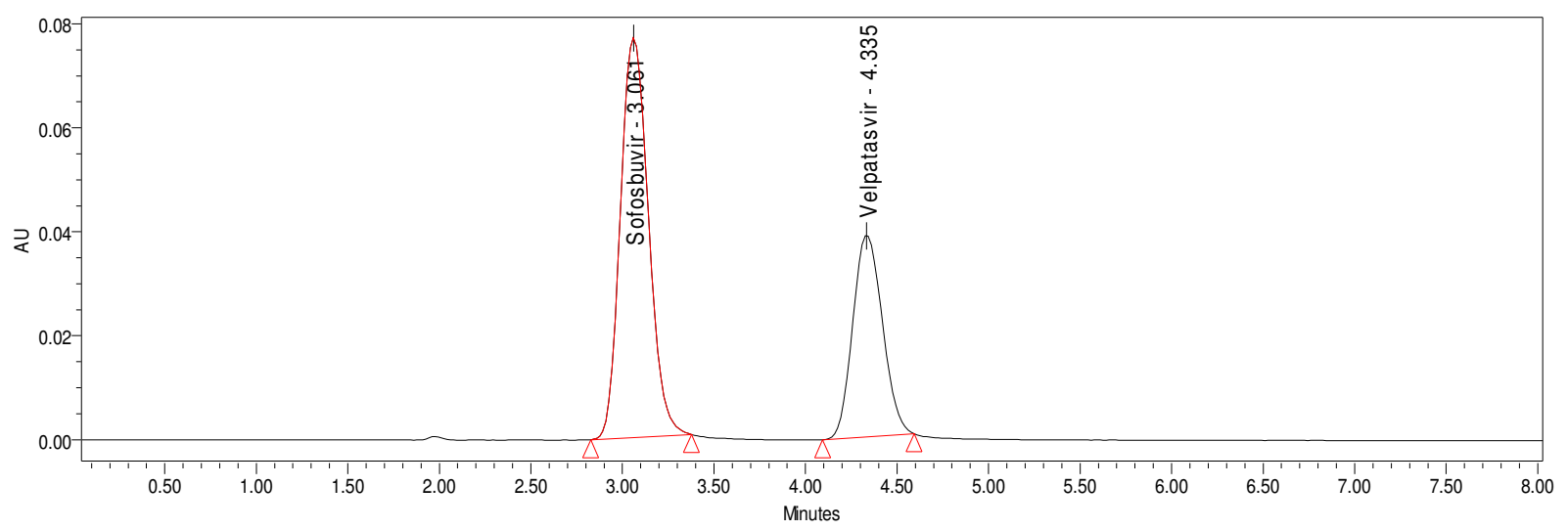

Fig.-8: Accuracy (50\%) Chromatogram

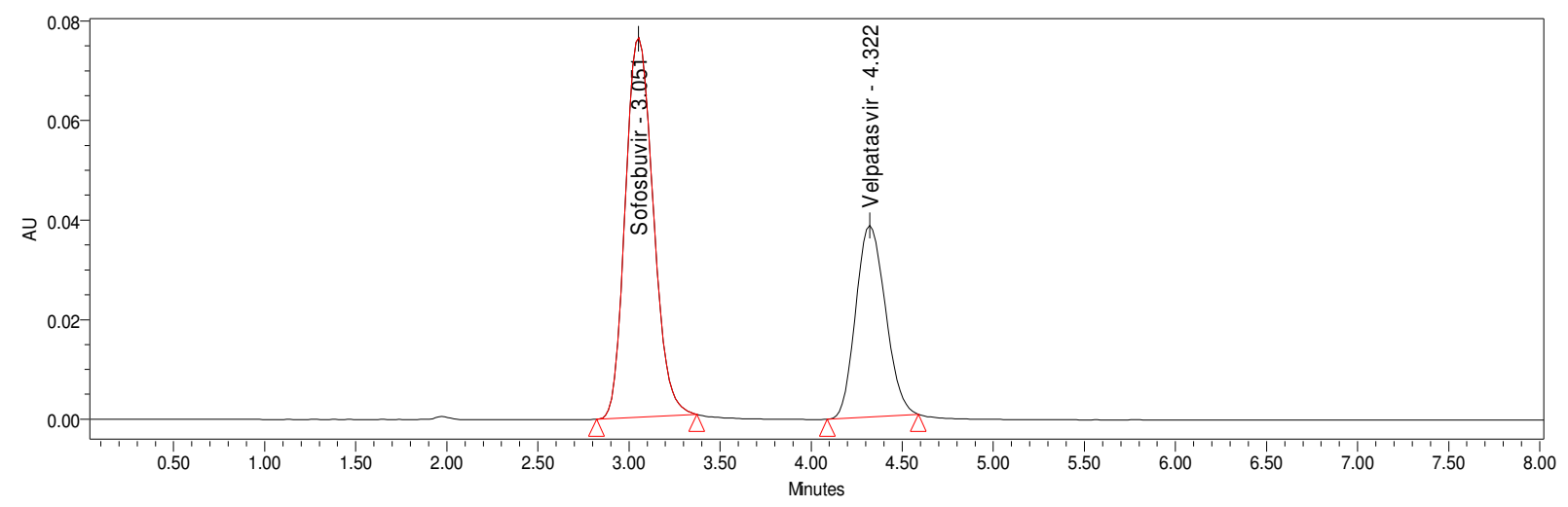

Fig.-9: Accuracy (150\%) chromatogram

\section{Precision}

\section{System Precision}

System precision was conducted to make sure that the HPLC system was perfect. WS Solution at $40 \mathrm{ppm}$ with respect to both SOF and VEL together in five replicates were injected and the chromatograms were analyzed. The \% RSD for PA and \% Assay for SOF and VEL were with in the acceptance limit of not more than 2 (Table-7).

Table-7: System Precision

\begin{tabular}{c|c|c|c|c}
\multicolumn{5}{c}{ Table-7: System Precision } \\
\hline \multirow{2}{*}{ Trial } & \multicolumn{2}{|c}{ SOF } & \multicolumn{2}{c}{ VEL } \\
\cline { 2 - 5 } & PA & \% Assay & PA & $\%$ Assay \\
\hline 1 & 9437784 & 99.74 & 323112 & 99.98 \\
\hline 2 & 9437412 & 99.14 & 323452 & 99.30 \\
\hline 3 & 9430257 & 99.62 & 323742 & 99.60 \\
\hline 4 & 9438431 & 99.72 & 323047 & 99.84 \\
\hline 5 & 9438754 & 99.42 & 323087 & 99.72 \\
\hline Mean & 94367079 & 99.13 & 3231472 & 99.71 \\
\hline SD & 10475.12 & 0.24746 & 7452.4712 & 0.425 \\
\hline RSD & 0.7842 & 0.31713 & 0.752411 & 0.240 \\
\hline
\end{tabular}

\section{Method Precision}

TS solution at $40 \mathrm{ppm}$ with respect to both SOF and VEL was injected in six replicates and chromatograms studied. 


\section{RASĀYAN J. Chem.}

Vol. 11 | No. 1 |392 - 400 | January - March | 2018

The \%RSD for PA for SOF and VEL were less than 2. The individual assay of SOF and VEL were within the limits of not less than $98 \%$ and not more than $102 \%$. (Table- 8 )

Table-8: Method Precision

\begin{tabular}{c|c|c|c|c}
\hline \multirow{2}{*}{ Trial } & \multicolumn{2}{|c|}{ SOF } & \multicolumn{2}{c}{ VEL } \\
\cline { 2 - 5 } & PA & \% Assay & PA & \% Assay \\
\hline 1 & 9432571 & 99.25 & 323584 & 99.54 \\
\hline 2 & 9438475 & 99.12 & 323054 & 99.72 \\
\hline 3 & 9434752 & 98.12 & 323847 & 99.31 \\
\hline 4 & 9430487 & 99.52 & 323751 & 99.84 \\
\hline 5 & 9436547 & 98.84 & 323814 & 99.42 \\
\hline 6 & 9437841 & 99.54 & 323745 & 99.32 \\
\hline Mean & 9438845 & 99.56 & 323875 & 99.87 \\
\hline SD & 147205 & 0.54213 & 3240.5412 & 0.7845 \\
\hline RSD & 0.7451 & 0.412 & 0.54721 & 0.874654 \\
\hline
\end{tabular}

\section{Intermediate Precision}

TS at $40 \mathrm{ppm}$ with respect to both SOF and VEL was taken and six replicate trials were run on two different days. The chromatograms collected for method precision were considered as day one chromatograms. The \%RSD and \% Assay calculated from the chromatograms on two different days for individual SOF and VEL met the acceptance limits. The method developed was thus precise.

\section{Robustness}

Small variation in the experimental conditions (Table-9) showed little or no effect. The \%RSD for PA and RT were within the acceptance limits (Table-10).

Table-9: Experimental conditions

\begin{tabular}{c|c|c|c}
\hline Changed Value & I & II & III \\
\hline $\begin{array}{c}\text { M.P FR } \\
(\mathrm{ml} / \mathrm{min})\end{array}$ & 0.8 & 1.0 & 1.2 \\
\hline Temp $\left({ }^{\circ} \mathrm{C}\right)$ & 20 & 25 & 30 \\
\hline Buffer $\mathrm{pH}$ & 3.1 & 3.2 & 3.3 \\
\hline
\end{tabular}

Table-10: Robustness Data

\begin{tabular}{|c|c|c|c|c|c|c|c|c|c|c|}
\hline & \multirow[t]{2}{*}{ Value } & \multicolumn{3}{|c|}{ MP FR } & \multicolumn{3}{|c|}{ Temp } & \multicolumn{3}{|c|}{ Buffer $\mathrm{pH}$} \\
\hline & & 0.8 & 1.0 & 1.2 & 20 & 25 & 30 & 3.1 & 3.2 & 3.3 \\
\hline \multirow{3}{*}{ SOF } & $\begin{array}{c}\text { Mean } \\
\mathrm{PA}(\mathrm{n}=3)\end{array}$ & 9416963 & 9436039 & 9456257 & 9376469 & 9454160 & 9546386 & 9341702 & 947503 & 9562431 \\
\hline & SD & 1525.937 & 2597.38 & 4338.7 & 8493.9 & 4845.5 & 28271.8 & 17083 & 14889 & 13982.2 \\
\hline & $\%$ RSD & 0.0162 & 0.0275 & 0.045 & 0.0905 & 0.0512 & 0.2961 & 0.1828 & 0.15714 & 0.1462 \\
\hline \multirow{3}{*}{ VEL } & $\begin{array}{c}\text { Mean } \\
\operatorname{PA}(n=3)\end{array}$ & 321727.7 & 323472 & 324794.7 & 318496 & 32624.1 & 336844 & 314742 & $\begin{array}{c}327722 \\
.3\end{array}$ & 332496.3 \\
\hline & SD & 161.97 & 395.186 & 75.566 & 562.3 & 2826.4 & 2575.6 & 2486.2 & 2264.3 & 2845.466 \\
\hline & $\%$ RSD & 0.0503 & 0.12217 & 0.0232 & 0.176 & 0.8663 & 0.7646 & 0.7899 & 0.6973 & 0.855789 \\
\hline
\end{tabular}

\section{LOD}

From the regression line the LOD for SOF and VEL were calculated as $0.475 \mathrm{ppm}$ and $0.65 \mathrm{ppm}$ respectively.

\section{LOQ}

From the regression line the LOQ for SOF and VEL were calculated as $1.44 \mathrm{ppm}$ and $1.98 \mathrm{ppm}$ respectively. 
RASĀYAN $J$. Chem.

Vol. 11 | No. 1 |392 - 400 | January - March | 2018

\section{CONCLUSION}

Simultaneous RP- HPLC method for estimation of SOF and VEL in their combined tablet dosage form was developed and validated in accordance with the ICH instructions. All the validation parameters met the acceptance limits. The developed method can be used for regular quality control analysis.

\section{REFERENCES}

1. https://en.wikipedia.org/wiki/Hepatitis c

2. https://en.wikipedia.org/wiki/Sofusbuvir

3. https://pubchem.ncbi.nlm.nih.gov/compound/velpatasvir

4. P. Mohanvikas and T.Satyanarayana, World Journal of Pharmacy and Pharmaceutical Sciences, 5(5), 775(2016).

5. V. Ravikumar, C. V. S.Subramanyam and G. Veerabhadram, International Journal of Pharmacy, 6(2), 121 (2016).

6. B. Zaman, F. Siddique and W. Hassan, Chromatographia, 79, 1605 (2016)

7. B. Rajkumar, and K.V. Subramanyam, Indo American Journal of Pharmaceutical Research, 6(2), 4508 (2016).

8. V. Ashokchakravarthy, BBV. Sailaja, A. P. Kumar, Asian Journal of Pharmaceutical and Clinical Research, 9(3), 61(2016).

9. S. Madhavi, A. Prameela Rani, International Journal of Pharmacy and Pharmaceutical Sciences, 9(3), (2017)

10. https://www.fda.gov/Drugs/GuidanceComplianceRegulatoryInformation/ Guidance/ucm265700.htm

[RJC-1931/2017] 